\title{
Study of association of maternal vitamin $D$ deficiency with hypocalcaemic seizures in exclusively breast-fed infants
}

\author{
Pradeep Nanjappa Shetty ${ }^{1},{ }^{*}$ Girish Gopal $^{2}$, Aruna A E \\ Sri Lanka Journal of Child Health, 2022; 51(1): 106-110 \\ DOI: http://dx.doi.org/10.4038/sljch.v51i1.10007
}

\begin{abstract}
Background: Hypocalcaemia is a common metabolic cause of seizures in early infancy. Improper formula feeds and lack of breast feeding have been established causes of hypocalcaemia and subsequent rickets in infants. There is a close correlation between the Vitamin D status of mothers and their infants. There is limited information regarding the vitamin D status of lactating mothers and their hypocalcaemic infants.
\end{abstract}

Objectives: To determine the association between maternal vitamin D levels and hypocalcaemic seizures in exclusively breast-fed infants.

Method: We conducted an analytical cross-sectional study from January 2018 to June 2019 in Cheluvamba Hospital, Mysore Medical College and Research Institute, Mysuru, India in a cohort of 40 mother-infant dyads who were exclusively breastfed and had hypocalcaemic seizures. Serum calcium, phosphorus and alkaline phosphatase of the infants and serum 25 hydroxyvitamin D [25 (OH) D] levels of both mothers and infants were measured and the results were analysed.

Results: Mean ages of the studied infants and mothers were $12.95 \pm 8.13$ weeks and $22.15 \pm 2.46$ years respectively. All infants had normal anthropometry whereas $70 \%$ of the mothers were underweight. Of the 40 infant-mother pairs studied, $34(85 \%)$ infants and $33(82.5 \%)$ mothers had subnormal $25(\mathrm{OH})$ D levels. Mean serum calcium, phosphorus and alkaline phosphatase levels in the infant were $6.46 \pm 1.05 \mathrm{mg} / \mathrm{dl}, 3.63 \pm 1.03 \mathrm{mg} / \mathrm{dl}$ and

$\overline{{ }^{1} \text { Associate Professor of Paediatrics, }{ }^{3} \text { Post-graduate }}$ student Mysore Medical College and Research Institute, Mysuru, India

*Correspondence: girishgpl@gmail.com

https//orcid.org/ 0000-0001-9444-1816

(Received on 12 May 2021: Accepted after revision on 18 June 2021)

The authors declare that there are no conflicts of interest

Personal funding was used for the project.

Open Access Article published under the Creative

Commons Attribution CC-BY (c) (i) License
$785.87 \pm 235.49 \mathrm{IU} / \mathrm{L}$ respectively. Mean $25(\mathrm{OH})$ $\mathrm{D}$ levels in the infants and mothers were $20.85 \pm$ $5.80 \mathrm{ng} / \mathrm{ml}$ and $21.95 \pm 4.45 \mathrm{ng} / \mathrm{ml}$ respectively. We found significant correlation between the serum calcium levels and the $25(\mathrm{OH})$ levels of the infants and mothers $(p<0.001)$; similar correlation was found between the infant and maternal $25(\mathrm{OH}) \mathrm{D}$ level $(p<0.001)$.

Conclusions: Most exclusively breast-fed infants with hypocalcaemic seizures had subnormal 25 $(\mathrm{OH}) \mathrm{D}$ levels and they strongly correlated with the maternal $25(\mathrm{OH})$ D levels.

(Keywords: Exclusive breast feeding, Hypocalcaemic seizures, Vitamin D deficiency)

\section{Introduction}

World Health Organisation (WHO) has estimated that 1.3 million infant deaths can be prevented in over 42 countries by improving the rate of exclusive breast feeding ${ }^{1}$. Hypovitaminosis D is highly prevalent across all age groups in India ${ }^{2,3}$. Maternal vitamin D deficiency can delay growth, reduce bone ossification and alter calcium metabolism in their offspring during infancy ${ }^{4,5}$. Pre-existing hypovitaminosis $\mathrm{D}$ can worsen during pregnancy and lactation due to active transplacental transport of calcium and vitamin D to the developing fetus and through milk to breast fed infants. This situation is likely to be compounded as only few women received proper calcium and vitamin D supplements during pregnancy and lactation ${ }^{6}$. World over, increasing trends of subnormal vitamin D levels in infants with hypocalcaemic seizures have been reported $^{7}$. Studies have reported a 20-82\% prevalence of hypovitaminosis D in exclusively breast-fed infants ${ }^{8,9}$. However, there is a paucity of similar data in hypocalcaemic infants in developing countries. An infant born to a mother with hypovitaminosis D is susceptible to develop rickets and symptomatic hypocalcaemia by 4-6 months of age $^{8,9,10}$.

\section{Objectives}

To estimate the incidence of hypovitaminosis D in our cohort of exclusively breast fed hypocalcaemic infants and to correlate it with the maternal vitamin D levels. 


\section{Method}

This analytical cross-sectional study was conducted at Cheluvamba Hospital attached to Mysore Medical College and Research Institute from January 2018 to June 2019. All term singleton infants, aged 0-24 weeks, who had unprovoked seizures and came to our Emergency Room were evaluated as per department protocol, which included a complete blood count (CBC), random blood sugar (RBS), Creactive protein (CRP) and total serum calcium level. Such infants who had a serum calcium level $<8.8 \mathrm{mg} / \mathrm{dl}$ with a normal CBC, RBS and CRP and their mothers were identified as potential subjects for inclusion in our study. Infants born prematurely, receiving vitamin D supplements, having acute febrile illness, cerebral palsy, congenital brain malformations, and any other seizure precipitating conditions like birth asphyxia, meningitis, and systemic illness were excluded from the study.

A detailed clinical examination of the infant was done. Demographic details and data to calculate the body mass index (BMI) of the mother, socioeconomic status (SES, as per modified Kuppuswamy classification - scoring system based on per capita income, education and occupation of head of family) $)^{11}$ and sun exposure index of the mothers and their infants [determined by multiplying \% Body Surface Area (BSA) exposure by hours of sunlight exposure per week] were also noted $^{12}$. BMI of the mother was calculated and classified in accordance with WHO as underweight $\left(<18.5 \mathrm{~kg} / \mathrm{m}^{2}\right)$, normal $\left(18.5-24.99 \mathrm{~kg} / \mathrm{m}^{2}\right)$ or overweight $\left(>25 \mathrm{~kg} / \mathrm{m}^{2}\right)$. Mothers with SES score of $<5,5-10,11-15,16-25$ and $26-29$ were classified as belonging to lower, upper lower, lower middle, upper middle and upper SES class respectively. Two $\mathrm{ml}$ of venous blood of both the mother and infant were drawn for analysis. Serum phosphorus and alkaline phosphatase levels of the infant and 25 $(\mathrm{OH})$ D levels of both infant and mother were estimated. Serum calcium was estimated by the modified Arzenazo III method, serum phosphorus by the Molybdate UV method, serum alkaline phosphatase by Liquichek enzymatic colour spectrophotometry - 405nm - DGKC method (Deutsche Gesellschaft fur Klinsche Chemie) and 25 (OH) D level by ELISA using the Calbiotech vitamin D kit. Within 48 hours of admission of the child, details of the demography, clinical examination and investigations were entered into a pre-formed and pre-tested proforma for analysis, thereby ensuring a zero-dropout rate. Hypocalcaemia was diagnosed when the total serum calcium level was less than $8.8 \mathrm{mg} / \mathrm{dl} ; 25(\mathrm{OH}) \mathrm{D}$ levels of $\geq 30 \mathrm{ng} / \mathrm{ml}$ were considered as sufficient (normal), $21-29 \mathrm{ng} / \mathrm{ml}$ as insufficient and $\leq 20 \mathrm{ng} / \mathrm{ml}$ as deficient as per the recommendations of the Endocrine Society ${ }^{13}$

Ethical issues: Approval for the study was obtained from the Institutional Ethics Committee of Mysore Medical College and Research Institute, Mysore, India (EC REG:ECR/134/Inst/KA/2013/RR16). Written informed consent was obtained from the parents/caregivers of the infants enrolled in the study.

Statistical analysis: The data collected were tabulated in Microsoft Excel and analysed using SPSS version 20.0. Continuous data were presented either as mean (standard deviation) or median (range), whereas categorical data were presented as frequency (percentage). Cramer's V test was used to correlate categorical variables whereas Pearson's product-moment test was used to correlate continuous variables with maternal vitamin D. A two tailed $p$ value $<0.05$ was considered significant.

\section{Results}

Forty infant-mother pairs who fulfilled the inclusion criteria were subjected to clinical and biochemical assessment. Among the 40 infants included, 40\% were in the age group of $0-2$ months (mean age 12.95 \pm 8.13 weeks) and $60 \%$ were males. All of them had normal anthropometry (mean weight $5.68 \pm 1.61 \mathrm{~kg}$, mean length $58.65 \pm 6.63 \mathrm{~cm}$, mean head circumference $38.45 \pm 3.21 \mathrm{~cm})$. Only $6(15 \%)$ infants were exposed to some form of sunlight for more than 2 hours in a day (Table 1).

Table 1: Demographic characteristics of the study population

\begin{tabular}{|c|c|c|c|c|c|c|}
\hline \multirow{2}{*}{ Parameter } & 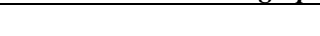 & \multicolumn{2}{|c|}{ Infants $(n=40)$} & & \multicolumn{2}{|c|}{ Mothers $(n=40)$} \\
\hline & & n (\%) & Mean \pm SD & & n (\%) & Mean \pm SD \\
\hline Age & $\begin{array}{l}0-2 \text { months }(0-8 \text { weeks }) \\
2-4 \text { months }(8-16 \text { weeks }) \\
4-6 \text { months }(16-24 \text { weeks })\end{array}$ & $\begin{array}{l}16(40) \\
12(30) \\
12(30\end{array}$ & $12.95 \pm 8.13$ & $\begin{array}{l}\text { Less than } 20 \text { years } \\
21-25 \text { years } \\
\text { More than } 25 \text { years }\end{array}$ & $\begin{array}{l}08(20) \\
30(75) \\
02(05)\end{array}$ & $22.15 \pm 2.46$ \\
\hline Gender & $\begin{array}{l}\text { Male } \\
\text { Female }\end{array}$ & $\begin{array}{l}24(60) \\
16(40)\end{array}$ & & & & \\
\hline $\operatorname{BMI}\left(\mathrm{kg} / \mathrm{m}^{2}\right)$ & & & & $\begin{array}{l}\text { Underweight } \\
\text { Normal }\end{array}$ & $\begin{array}{l}28(70) \\
12(30) \\
\end{array}$ & $17.12 \pm 2.77$ \\
\hline SES & $\begin{array}{l}\text { Upper lower } \\
\text { Lower middle }\end{array}$ & $\begin{array}{l}16(40) \\
24(60)\end{array}$ & & $\begin{array}{l}\text { Upper lower } \\
\text { Lower middle }\end{array}$ & $\begin{array}{l}16(40) \\
24(60)\end{array}$ & \\
\hline Sun exposure index & & & $23.16 \pm 3.48$ & & & $178.06 \pm 16.52$ \\
\hline
\end{tabular}

Of the infants $85 \%$ were born to nonconsanguineous married couples, $87.5 \%$ were born to primigravida mothers and $60 \%$ were from a lower middle socio-economic status (SES score 11-15). Of 
the mothers $75 \%$ were in the age group $21-25$ years (mean age $22.15 \pm 2.46$ years) and only $30 \%$ had normal BMI, whereas $70 \%$ were underweight (mean BMI $\left.17.12 \pm 2.77 \mathrm{~kg} / \mathrm{m}^{2}\right)$. Majority of the mothers $(33 / 40-82.5 \%)$ were housewives (Table 1$)$. The mean $25(\mathrm{OH}) \mathrm{D}$ levels were $21.95 \pm 4.45 \mathrm{ng} / \mathrm{ml}$ and $20.85 \pm 5.80 \mathrm{ng} / \mathrm{ml}$ in the mothers (highest -37.80 $\mathrm{ng} / \mathrm{ml}$; lowest - $14.50 \mathrm{ng} / \mathrm{ml}$ ) and infants (highest $34.50 \mathrm{ng} / \mathrm{ml}$; lowest - $12.20 \mathrm{ng} / \mathrm{ml}$ ) respectively (Table 2).

Table 2: Biochemical parameters of the study population

\begin{tabular}{|c|c|c|c|c|c|c|c|c|c|c|}
\hline \multirow{2}{*}{\multicolumn{3}{|c|}{ Study population }} & \multicolumn{8}{|c|}{ Biochemical parameter } \\
\hline & & & \multirow{2}{*}{\multicolumn{2}{|c|}{$\frac{\text { S. Calcium }(\mathrm{mg} / \mathrm{dl})}{6.46 \pm 1.05}$}} & \multirow{2}{*}{\multicolumn{2}{|c|}{$\begin{array}{c}\text { S. Phosphorus }(\mathrm{mg} / \mathrm{dl}) \\
3.63 \pm 1.03\end{array}$}} & \multicolumn{2}{|c|}{ S. Alk. phosphatase (IU/L) } & \multirow{2}{*}{\multicolumn{2}{|c|}{$\begin{array}{c}25(\mathrm{OH}) \mathrm{D} \text { level }(\mathrm{ng} / \mathrm{ml}) \\
20.85 \pm 5.80\end{array}$}} \\
\hline \multirow{2}{*}{$\begin{array}{l}\text { Infants } \\
(\mathrm{n}=40)\end{array}$} & \multicolumn{2}{|c|}{ Mean \pm SD } & & & & & & & & \\
\hline & Min & Max & 3.8 & 8.10 & 2.1 & 5.8 & 383 & 1245 & 12.20 & 34.50 \\
\hline \multirow{2}{*}{$\begin{array}{l}\text { Mothers } \\
(\mathrm{n}=40)\end{array}$} & \multicolumn{2}{|c|}{ Mean \pm SD } & & & & & & & \multicolumn{2}{|c|}{$21.95 \pm 4.45$} \\
\hline & Min & Max & & & & & & & 14.50 & 37.80 \\
\hline
\end{tabular}

Maternal $25(\mathrm{OH})$ D level had a significant correlation with BMI $(p<0.001)$, socio-economic status $(p=0.026)$ and sun exposure index $(p<$ $0.001)$. We did not find similar correlation with age and parity.

Thirty four (85\%) infants and $33(82.5 \%)$ mothers had subnormal (insufficient + deficient) levels of 25 $(\mathrm{OH})$ D. Of these 33 mothers, 30 offspring demonstrated subnormal and the remaining 3 had normal (sufficient) $25(\mathrm{OH}) \mathrm{D}$ level which was statistically significant $(p<0.001)$. Out of the remaining 7 mothers who had normal $25(\mathrm{OH}) \mathrm{D}$ level, 4 offspring demonstrated subnormal and the remaining 3 had normal $25(\mathrm{OH}) \mathrm{D}$ level (Tables 3 and 4). We also found a significant correlation between the mean serum calcium level of the infants with the infant and maternal $25(\mathrm{OH}) \mathrm{D}$ level $(p<$ 0.001) (Table 5).

Table 3: Distribution of study population based on 25 (OH) D levels

\begin{tabular}{|c|c|c|c|c|c|}
\hline \multirow{2}{*}{\multicolumn{2}{|c|}{25 (OH) D level (ng/ml) }} & \multicolumn{4}{|c|}{ Study population } \\
\hline & & & $n=40)$ & Moth & $n=40)$ \\
\hline \multicolumn{2}{|c|}{ Normal/Sufficient $(\geq 30)$} & \multicolumn{2}{|c|}{$06(15 \%)$} & \multicolumn{2}{|c|}{$07(17.5 \%)$} \\
\hline \multirow{2}{*}{$\begin{array}{l}\text { Subnormal/Decreased } \\
(<30)\end{array}$} & Insufficiency (21-29) & $26(65 \%)$ & \multirow[t]{2}{*}{$34(85 \%)$} & $27(67.5 \%)$ & \multirow[t]{2}{*}{$33(82.5 \%)$} \\
\hline & Deficiency $(\leq 20)$ & $8(20 \%)$ & & $06(15 \%)$ & \\
\hline
\end{tabular}

Table 4: Distribution of infants based on maternal 25 (OH) D levels

\begin{tabular}{|l|c|c|}
\hline \multirow{2}{*}{ Infant 25 (OH) level } & \multicolumn{2}{|c|}{ Maternal 25 (OH) D levels } \\
\cline { 2 - 3 } & Subnormal/Decreased $(\boldsymbol{n}=33)$ & Normal $(\boldsymbol{n}=7)$ \\
\hline Subnormal/Decreased $(\mathrm{n}=34)$ & 30 & 4 \\
\hline Normal $(\mathrm{n}=6)$ & 3 & 3 \\
\hline
\end{tabular}

Table 5: Correlation of infant and maternal parameters with maternal $25(\mathrm{OH}) \mathrm{D}$ levels

\begin{tabular}{|c|c|c|c|}
\hline \multirow{2}{*}{\multicolumn{2}{|c|}{ Parameter }} & \multicolumn{2}{|c|}{ Maternal $25(\mathrm{OH})$ D level } \\
\hline & & $r$ value & $p$ value \\
\hline \multirow{5}{*}{ Infant } & Serum calcium & 0.545 & $<0.001$ \\
\hline & Serum phosphorus & 0.065 & 0.530 \\
\hline & Serum alkaline phosphatase & 0.480 & $<0.001$ \\
\hline & $25(\mathrm{OH}) \mathrm{D}$ level & 0.612 & $<0.001$ \\
\hline & Sun exposure index & 0.317 & 0.032 \\
\hline \multirow{3}{*}{ Maternal } & Body mass index (BMI) & 0.494 & $<0.001$ \\
\hline & Socio-economic status (SES) & 0.356 & 0.026 \\
\hline & Sun exposure index & 0.592 & $<0.001$ \\
\hline
\end{tabular}

\section{Discussion}

This potential research to associate $25(\mathrm{OH}) \mathrm{D}$ levels in hypocalcaemic infants with the $25(\mathrm{OH}) \mathrm{D}$ levels in their mothers was conducted with a sample of 40 infants aged less than 6 months. Most of them were aged between 2-4 months with a male to female ratio of 1.5:1. Adequate levels of vitamin D in the human milk are required to ensure adequate mineralisation of the long bones, to maintain normal serum calcium level and to improve linear growth. Due to the increased prevalence of hypovitaminosis $\mathrm{D}$ in pregnant and lactating mothers, the incidence of hypocalcaemic seizures and subsequent rickets has increased in early infancy. Hypocalcaemia could be attributed to the increased metabolic demands of rapid growth, resulting in development of symptomatic hypocalcaemia even before any radiological changes of rickets can occur ${ }^{5,6}$. 
In our study, 30 out of the 40 infant-mother pairs had hypovitaminosis D. Of the remaining 10 pairs, there were 3 pairs where hypovitaminosis $\mathrm{D}$ was found in the mother but their infants had normal vitamin D levels. Among the remaining 7 pairs, all the mothers and only 3 infants had normal vitamin D levels. Of the 40 mothers $33(82.5 \%)$ had hypovitaminosis D probably because they were underweight and had not taken antenatal/ postnatal calcium and vitamin D supplements. Another important factor which we could identify was that these mothers hailed from the city and were housewives with limited exposure to sunlight and therefore had a low sun exposure index. On the contrary, the remaining $7(17.5 \%)$ who had normal levels of $25(\mathrm{OH}) \mathrm{D}$ hailed from a rural background and were manual labourers who worked in the open fields during most of the day. Also, the 6 infants who had normal vitamin D levels were exposed to some form of sunlight for at least a couple of hours in a day. This underscores the fact that adequate exposure to sun also has an important role in the endogenous production of vitamin $\mathrm{D}$.

Dawodu A, et $a l^{12}$ studied 90 healthy exclusively breast-fed infants and their mothers and emphasized the importance of sun exposure in maintaining normal $25(\mathrm{OH}) \mathrm{D}$ levels. Seth A, et al ${ }^{6}$ analysed 180 healthy lactating mothers and their exclusively breast-fed infants and found high prevalence of hypovitaminosis D in lactating mothers and their infants. They also found that infants born to mothers with hypovitaminosis D had 3.8 times higher risk of developing hypovitaminosis $\mathrm{D}$ and subsequent symptomatic hypocalcaemia and rickets as compared to those born to mothers with normal vitamin $\mathrm{D}$ level. Balasubramanian $\mathrm{S}$, et $a l^{7}$ studied 50 infants with hypocalcaemic seizures and found that 13 of those infants who were exclusively breast fed had hypovitaminosis D and all their mothers were also deficient in vitamin D. Similarly, Pal BR, et $a l^{14}$ also found a consistent relationship of deficient maternal vitamin D levels and evidence of vitamin D deficiency in their exclusively breast-fed infants who had hypocalcaemia and rickets. We have shown that the majority of the hypocalcaemic infants $(88.2 \%$ i.e. $30 / 34)$ with hypovitaminosis D were being exclusively breast fed by their mothers who were also deficient in vitamin D. The strong correlation we found between maternal and infant serum $25(\mathrm{OH}) \mathrm{D}$ levels are similar to those found by Seth $\mathrm{A}$, et $a l^{6}$, S. Balasubramanian $\mathrm{S}$, et $a l^{7}$, and Pal BR, et $a l^{14}$. However, these findings were in contrast to the observations of Sharma $\mathrm{J}$, et $a l^{15}$ who did not find any association between maternal hypovitaminosis D and hypocalcaemia in exclusively breast-fed infants. Greer FR, et $a l^{16}$ reported that vitamin D un-supplemented breast fed infants had no evidence of hypovitaminosis D during the first 6 months of life. However, based on the observations in Alaska, UK and India exclusive breast feeding is an important attribute in the development of hypocalcaemia in early infancy; our study too provides similar evidence ${ }^{7,17}$.

Limitations of our study include a moderate sample size and the population included may not be representative of all communities. Also, the association of sun exposure behaviour was based on the reports by the mother and was subject to recall bias. In addition, we did not evaluate and correlate the radiological evidence of rickets in hypocalcaemic infants with maternal vitamin D levels. We did not assess the parathormone levels in all these infants which may be important to decide the need for further evaluation in hypocalcaemic infants with normal $25(\mathrm{OH}) \mathrm{D}$ levels.

Our study emphasizes the need for adequate exposure to sunlight and for considering vitamin D supplements as a mandatory requirement for pregnant and lactating women and their exclusively breast-fed infants.

\section{Conclusions}

Most exclusively breast-fed infants with hypocalcaemic seizures had subnormal $25(\mathrm{OH}) \mathrm{D}$ levels and they strongly correlated with the maternal $25(\mathrm{OH}) \mathrm{D}$ levels.

\section{Acknowledgements}

We thank all the subjects and their parents for having taken part in this research. We also extend our gratitude to all our colleagues and post-graduate students who helped us to conduct this research.

\section{References}

1. Lauer JA, Betran PA, Barros AJD, de Onis M. Deaths and years of life lost due to suboptimal breast-feeding among children in the developing world: a global ecological risk assessment. Public Health Nutrition 2006; 9(6): 673-85. https://doi.org/10.1079/PHN2005891 PMid: 16925871

2. Salle BL, Gloricux FH, Lapillone A. Vitamin D status in breastfed term babies. Acta Paediatrica 1998; 87: 726-7. https://doi.org/10.1111/j.16512227.1998.t b01736.x

PMid: 9722243

3. Goswami R, Gupta N, Goswami D, Marwaha RK, Tandon N, Kochupülai N. Prevalence and significance of low 25hydroxyvitamin D concentrations in healthy subjects in Delhi. American Journal of Clinical Nutrition 2000; 72: 472-5. 
https://doi.org/10.1093/ajcn/72.2.472

PMid: 10919943

4. Marwaha RK, Tandon N, Reddy DR, Aggarwal R, Singh R, Sawhney RC, et al. Vitamin $\mathrm{D}$ and bone mineral density status of healthy school children in northern India. American Journal of Clinical Nutrition 2005; 82: 477-82.

https://doi.org/10.1093/ajen/82.2.477

5. Sachan A, Gupta R, Das V, Agarwal A, Awasthi PK, Bhatia V. High prevalence of vitamin D deficiency among pregnant women and their newborns in northern India. American Journal of Clinical Nutrition 2005; 81:1060-4.

https://doi.org/10.1093/ajen/81.5.1060

PMid: 15883429

6. Seth A, Marwaha RK, Singla B, Aneja S, Malhotra P, Sastry A, et al. Vitamin D nutritional status of exclusively breast-fed infants and their mothers. Journal of Pediatric Endocrinology and Metabolism 2009; 22: 241-6.

https://doi.org/10.1515/JPEM.2009.22.3.2 41

PMid: 19492580

7. Balasubramanian S, Shivabalan SO, Kumar PS. Hypocalcaemia due to Vitamin $\mathrm{D}$ deficiency in exclusively breast-fed infants. Indian Pediatrics 2006; 43: 24751.

8. Daaboul J, Sanderson S, Kristenson K, Kitson H. Vitamin D deficiency in pregnant and breast-feeding women and their infants. Journal of Perinatology 1997; 17(1): 10-4.

9. Atiq M, Suria ASQ, Ahmed I. Vitamin D status of breastfed Pakistani infants, Acta Paediatrica 1998; 87(7): 737-40. https://doi.org/10.1111/j.16512227.1998.t b01739.x

10. Ho ML, Yen HC, Tsang RC, Specker BL, Chen XC, Nichols BL. Randomized study of sunshine exposure and serum 25- OHD in breast fed infants in Beijing, China. Journal of Pediatrics 1985; 107: 928-31. https://doi.org/10.1016/S00223476(85)801 92-X

11. Park K. Park's Textbook of Preventive Medicine: Medicine and Social Sciences. 25th edition. Jabalpur: Banarsidas Bhanot; 2019. p 746.
12. Dawodu A, Zalla L, Woo JG, Herbers PM, Davidson BS, Heubli JE, et al. Heightened attention to supplementation is needed to improve the vitamin D status of breastfeeding mothers and infants when sunshine exposure is restricted. Maternal and Child Nutrition 2014; 10: 383-97. https://doi.org/10.1111/j.17408709.2012.0 0422.x

PMid: 22708508 PMCid: PMC3461108

13. Holick MF, Binkley NC, Bischoff-Ferrari HA, Gordon CM, Hanley DA, Heaney $\mathrm{RP}$, et al. Evaluation, treatment, and prevention of Vitamin D deficiency: An Endocrine Society clinical practice guideline. Journal of Clinical Endocrinology and Metabolism 2011; 96: 1911-30.

https://doi.org/10.1210/jc.2011-0385

PMid: 21646368

14. Pal BR. Rickets resurgence in the United Kingdom: improving antenatal management in Asians. Journal of Pediatrics 2001; 139: 337-8.

https://doi.org/10.1067/mpd.2001.114877 PMid: 11487770

15. Sharma J, Bajpai A, Kabra M, Menon PSN. Hypocalcaemia-clinical, biochemical, radiological profile and follow-up in a tertiary hospital in India. Indian Pediatrics 2002; 39: 276-81.

16. Greer FR, Marshall S. Bone mineral content, serum vitamin $\mathrm{D}$ metabolite concentrations, and ultraviolet light exposure in infants fed human milk with and without vitamin D2 supplements. Journal of Pediatrics 1989; 114: 204- 12. https://doi.org/10.1016/S00223476(89)807 84-X

17. Gessner BD, de Schweinitz E. Nutritional rickets among breastfed black and Alaska Native children: Acta Paediatrica 1995; 84: 941- 2 . https://doi.org/10.1037/e415492005-001 PMCid: PMC1388767 